\title{
Air-flow geometry in air sparging of fine-grained sands
}

\author{
J.W. Peterson · K.S. Murray · Y.I. Tulu • B.D. Peuler \\ D.A. Wilkens
}

\begin{abstract}
Laboratory visualization experiments in fineto very fine-grained sands (grain diameter $<0.21 \mathrm{~mm}$ ) reveal a previously unrecognized air-flow geometry. This air-flow geometry is termed "chamber flow" and is characterized by: (1) a significant horizontal component, (2) pervasive air-flow coverage within a region demarcated by a distinct, irregular boundary, and (3) the presence of predominantly vertical inlet and outlet channels. The attributes of chamber flow differ significantly from channelized flow and pervasive/bubbly flow, which occur at larger grain sizes and have been described in the literature by several researchers. Previous research, which indicates a dramatic increase in contaminant removal time in sediments $<0.2 \mathrm{~mm}$, indirectly corroborates the phenomena observed in this study. The extent of sediment column affected by chamber flow of sparge air ranges from $4-54 \%$ on an area basis, and is approximately $28 \%$ on a volume basis. These values indicate that chamber air flow has the potential to affect a much larger percentage of the sediment column than either channelized or pervasive/bubbly flow. Because of the irregularity of airflow chambers, in terms of both form and frequency, a detailed knowledge of stratigraphy is important to maximize air-sparging efficiency at sites where chamber flow is likely to occur.
\end{abstract}

Résumé Des expériences de visualisation en laboratoire dans des sables à grains fins à très fins (diamètre des grains inférieur à $0,21 \mathrm{~mm}$ ) ont mis en évidence une géométrie des écoulements d'air non reconnue auparavant. Cette géométrie des écoulements d'air est nommée «écoulement en cavité» et est caractérisée par (1) une

Received: 3 February 2000 / Accepted: 14 September 2000 Published online: 20 December 2000

(C) Springer-Verlag 2000

J.W. Peterson ( Y Y Y. Tulu · B.D. Peuler · D.A. Wilkens Department of Geological and Environmental Sciences,

Hope College, 35 E. 12th Street, Holland, Michigan 49423, USA e-mail: peterson@hope.edu

Fax: +1-616-3957118

K.S. Murray

Department of Natural Science, University of Michigan-Dearborn, 4901 Evergreen Road, Dearborn, Michigan 48128, USA composante horizontale significative, (2) un domaine d'expansion de l'écoulement d'air dans une région délimitée par une frontière distincte et irrégulière, et (3) la présence de chenaux essentiellement verticaux d'entrée et de sortie. Les caractères de l'écoulement en cavité diffèrent significativement de l'écoulement en chenaux et de l'écoulement expansif en bulle, qui se produisent pour des tailles de grains plus grandes et qui ont été décrits dans la littérature par plusieurs chercheurs. Une étude antérieure, qui indique un accroissement considérable du temps de déplacement d'un polluant dans des sédiments de granulométrie inférieure à $0,2 \mathrm{~mm}$, confirme indirectement les phénomènes observés dans ce travail. La part de la colonne de sédiment affectée par l'écoulement en cavité de l'air poussé et injecté va de 4 à $54 \%$ par rapport à la surface, et est d'environ $28 \%$ en volume. Ces valeurs indiquent que l'écoulement d'air en cavité a la capacité d'affecter une part de la colonne de sédiment bien plus vaste que l'écoulement en chenaux ou en bulles expansives. À cause de l'irrégularité des cavités d'écoulement d'air, à la fois en termes de forme et de fréquence, une connaissance détaillée de la stratigraphie est importante afin que l'injection de l'air soit maximale à des sites où il est probable que l'écoulement en cavité se produise.

Resumen La visualización de experimentos de laboratorio con arenas de tamaño de grano fino a muy fino (diámetro de grano inferior a $0,21 \mathrm{~mm}$ ) revela la existencia de una geometría de flujo de aire que no se había identificado previamente. Esta geometría es denominada "flujo en cámara" y se caracteriza por: (1) una componente horizontal significativa, (2) la cobertura generalizada del flujo de aire dentro de una región delimitada por un contorno distinto e irregular, y (3) la presencia de canales predominantemente verticales en las zonas de entrada y salida. Los atributos del flujo en cámara difieren significativamente del flujo en canales y el flujo generalizado/de burbujas, los cuales tienen lugar con tamaños mayores de grano y han sido descritos en la literatura por diversos investigadores. Las investigaciones previas, que indican un aumento enorme en el tiempo de descontaminación necesario para sedimentos de tamaño inferior a 0,2 $\mathrm{mm}$, corroboran de forma indirecta los fenómenos observados en este estudio. La zona afectada por flujo en cámara durante la inyección de aire en la columna de se- 
dimentos varía entre el 4 y el $54 \%$ en área, lo cual equivale aproximadamente al $28 \%$ en volumen. Estos valores indican que el flujo en cámara de aire tiene el potencial de afectar a un porcentaje de la columna mucho mayor que los otros mecanismos de flujo. Debido a la irregularidad de las cámaras de flujo de aire, tanto en forma como en frecuencia, es importante adquirir un conocimiento detallado de la estratigrafía para maximizar la eficacia de la inyección de aire en lugares en los que es probable el desarrollo de flujo en cámara.

Keywords air sparging - laboratory experiments/measurements $\cdot$ scale effects $\cdot$ remediation

\section{Background}

Air sparging has become a popular approach toward remediating groundwater contaminated with volatile organic compounds (VOCs) and chlorinated solvents. The basic concept is to inject air into the saturated zone of a contaminated aquifer. Injected air rises toward the vadose zone (unsaturated zone), scavenging VOCs from the groundwater by volatilization.

The actual manner in which air flows in the subsurface has been an important topic ever since air sparging was initiated as a valid substitute for traditional pumpand-treat technology. Because the natural subsurface at field sites cannot be observed, laboratory experimentation has contributed the majority of insights to air-flow geometry and patterns. These visualization experiments have been performed in a variety of ways, under a variety of controlled conditions. Most involve a transparent tank with two long dimensions and one short dimension. This "two-dimensional" apparatus allows the documentation of flow by direct observation in transparent media (Ji et al. 1993; Brooks et al. 1999), by indirect methods (Rutherford and Johnson 1996; Plummer et al. 1997), or by way of colorimetric techniques (Peterson et al. 1999, 2000).

Table 1 summarizes the observations of many researchers with respect to air-flow geometry in laboratory experiments. This research indicates that a fundamental change in flow characteristic occurs in the range of 1.3-1.84 mm grain-size diameter for natural sediments (Peterson et al. 1999) and between 1 and $3 \mathrm{~mm}$, and likely near $2 \mathrm{~mm}$, for spherical glass beads ( $\mathrm{Ji}$ et al. 1993; Brooks et al. 1999). The change is from "channel" or "channelized" flow in the smaller grain sizes to "bubble" or "pervasive/bubbly" flow in the larger grain sizes. In general, channel flow is air flow in discrete meandering channels, with areas of no air flow occurring between individual channels. Bubble flow is pervasive flow of air throughout an entire section of sedimentary column, within certain lateral boundary limits. Brooks et al. (1999) present a more detailed review of experimental results.

Hydrogeology Journal (2001) 9:168-176

\section{Objectives}

The spatial distribution of air, as it flows from a subsurface injection point up through unconsolidated sediments to the water table, has direct control on the effectiveness of the air-sparging endeavor. Because air is the transport medium for removal of the contaminant, remediation by volatilization will occur in those areas where air flow occurs. Where more of the sedimentary column is affected by air, more cleanup will occur. As discussed above, laboratory experimentation has established that air-flow geometry and resultant spatial distribution of air are dependent on grain size. Regardless of how consistent these findings are between experiments, an outstanding question has remained unaddressed: can it be assumed that "channelized flow" persists in smaller grain sizes of sediments than those previously investigated? Because many contaminated aquifers consist of particles less than $0.25 \mathrm{~mm}$ (i.e., fine to very fine sands on the Wentworth scale), the specific objective of this study was to investigate whether channelized flow persists in progressively smaller grain sizes, with the larger goal of evaluating the potential effectiveness of air sparging in natural fine to very fine sands.

\section{Methods}

\section{Apparatus}

Experiments were performed in two visualization tanks $(102 \mathrm{~cm}$ high $\times 102 \mathrm{~cm}$ wide $\times 5 \mathrm{~cm}$ deep and $127 \mathrm{~cm}$ high $\times 252 \mathrm{~cm}$ wide $\times 9 \mathrm{~cm}$ deep), constructed of acrylic, $1.6 \mathrm{~cm}$ thick. Figure 1 is a schematic diagram of the larger tank. Air sparging was simulated by introduction of

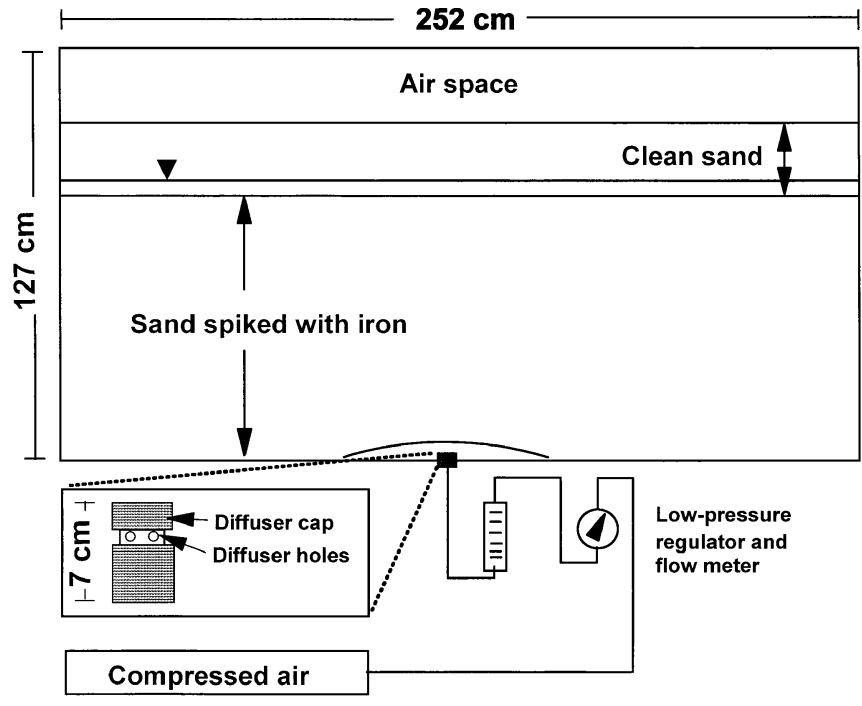

Fig. 1 General experimental design used in this study. Third dimension of tank is $9 \mathrm{~cm}$. Sand spiked with iron was capped by clean sand (not spiked with iron) of same grain-size distribution. An unsaturated zone existed within the clean sand layer. A mound of clean sand was also present around the diffuser. Close-up of diffuser is shown in inset 


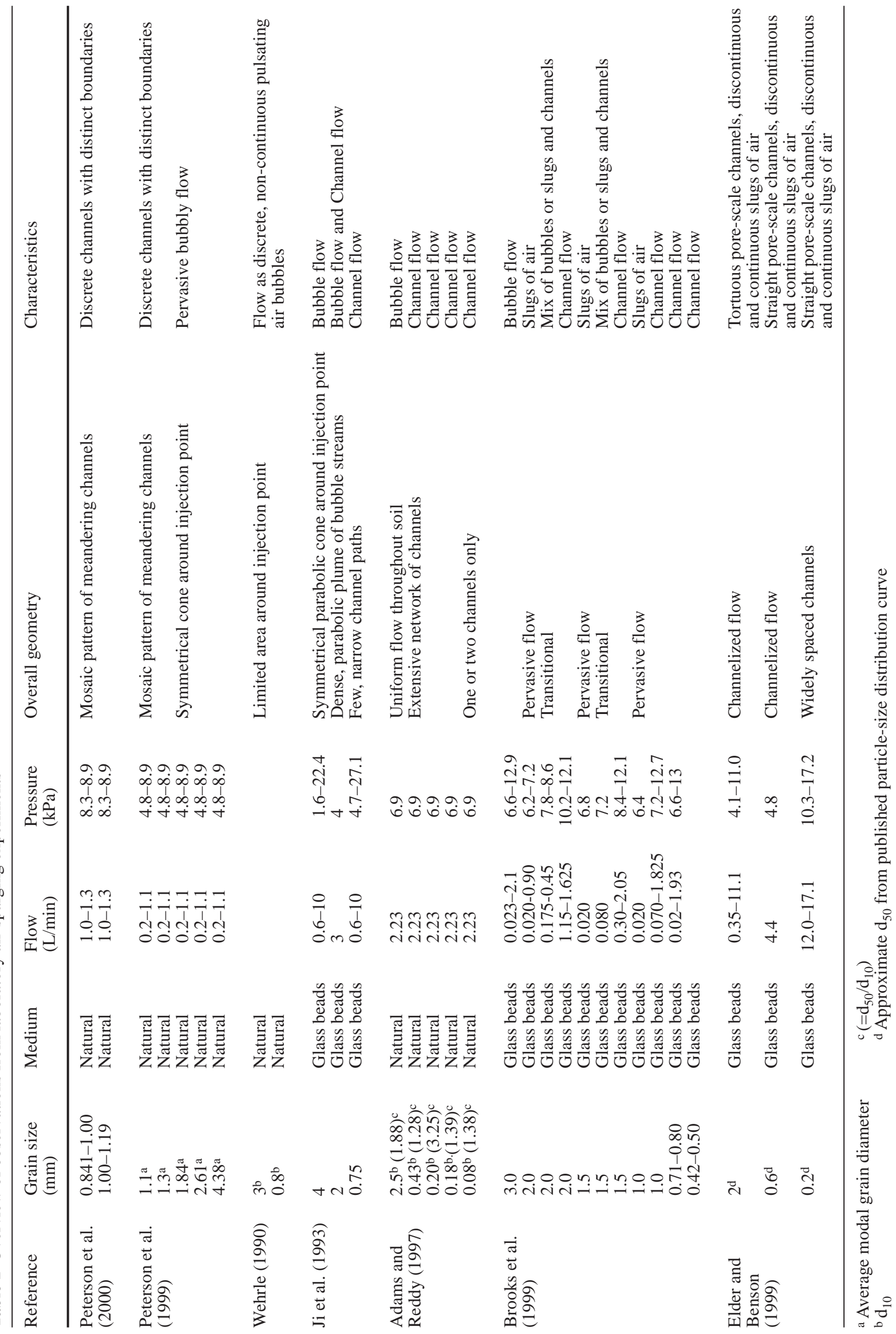


air through a 2-cm-diameter, 7-cm-tall, schedule 80 PVC diffuser at the bottom of the tank. The diffuser had six 1.5 -mm-diameter holes arranged symmetrically around the top, under a 1.9-cm-tall cap. The diffuser served as both the air-injection point and the water-entry port. Air delivery was controlled with a low-pressure regulator and flowmeter (Fig. 1). Sparge pressures for air ranged from 7.3-10.4 $\mathrm{kPa}(1.1-1.5 \mathrm{psi})$ for sand \#80 experiments, and from 9.5-13.4 $\mathrm{kPa}$ for dune-sand experiments. Entry pressures represent those pressures required for the air to just overcome the hydrostatic head and capillary pressure and begin flowing from the diffuser. Experiments were controlled on the basis of entry pressure, with flow being the dependent variable. Flow rates ranged from $0.33-2.3 \mathrm{~L} / \mathrm{min}$ for sand \#80 experiments, and from $0.33-2.4 \mathrm{~L} / \mathrm{min}$ for dune-sand experiments. Actual delivery pressures at a field site are a function of hydraulic head at the injection point plus system design and operation. Capillary pressures were estimated to be $1.3 \mathrm{kPa}$ for sand \#80 and $1.2 \mathrm{kPa}$ for the dune sand. These were calculated as the difference between entry pressure and hydrostatic pressure.

\section{Sands}

Sand from a very well-sorted Lake Michigan barrier dune in Grand Haven, Michigan, USA, was used in the experiments. A grain-size distribution for the sand is illustrated in Fig. 2. Organic-carbon content of the sand was estimated to be less than $0.3 \%$ by weight, based on step-wise heating and weighing to $600{ }^{\circ} \mathrm{C}$. One experiment was performed with the complete composite dune sand and two experiments with a separated fraction of the dune sand. The fraction was separated on a mechanical sieving machine using US standard mesh sieves (ASTM specification E-11), with pan \#80 retained for sparging experiments. Sand properties are given in Table 2. Shape analysis (sphericity and angularity) was performed by examining 100-200 individual grains per sand-size fraction under the binocular microscope and classifying them according to the system of Raymond

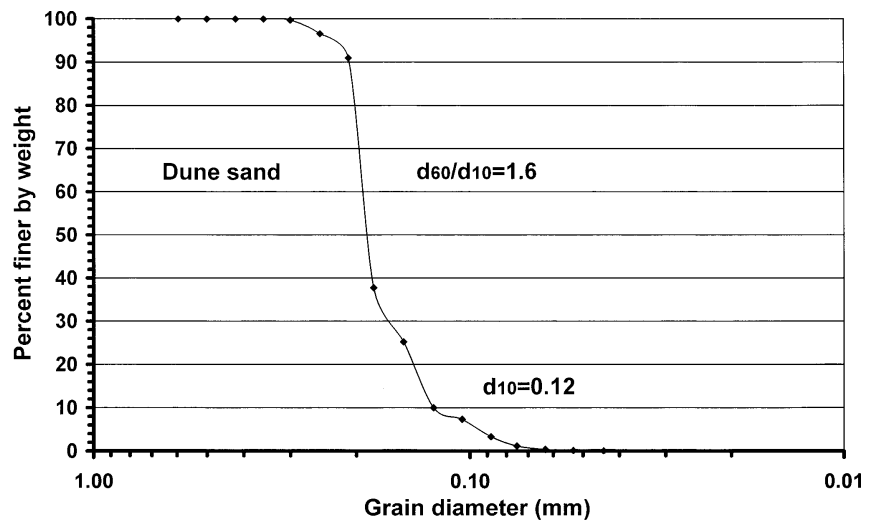

Fig. 2 Grain-size distribution of dune sand used in experiments. Effective grain size $\left(\mathrm{d}_{10}\right)$ and uniformity coefficient $\left(\mathrm{d}_{60} / \mathrm{d}_{10}\right)$ are shown

(1995). Porosity values of the sands were determined by multiple measurements of volume displacement in water. Measurements were performed by allowing samples of sand to settle in a graduated cylinder containing a known volume of water. This mimicked the procedure of loading the experimental apparatus. Twelve measurements were made for each sand used in the experiments. Values listed in Table 2 are within the common range for unconsolidated sediments (Fetter 1994) and are reported with one standard deviation of error.

Hydraulic conductivities were measured in the laboratory with a falling-head permeameter. Values listed in Table 2 are the average of eight individual conductivity experiments performed on each sand, and are reported with one standard deviation of error. Hydraulic conductivity was also calculated using several published empirical equations relating porosity, grain size, and hydraulic conductivity (Vukovic and Soro 1992). The measured values are within the range of calculated values. Calculated values should be considered as empirical estimates only; however, they do occur within the upper range expected for clean, unconsolidated sand (Freeze and Cherry 1979).

Table 2 Sand properties

\begin{tabular}{|c|c|c|c|c|c|}
\hline \multirow{5}{*}{ Table 2 Sand properties } & $\begin{array}{l}\text { Grain size }(\mathrm{mm}) \\
\text { and ASTM Pan \# }\end{array}$ & Sphericity & Angularity & $\begin{array}{l}\text { Hydraulic } \\
\text { conductivity }(\mathrm{m} / \mathrm{s})\end{array}$ & Porosity (\%) \\
\hline & Separated fraction & $\begin{array}{l}49 \% \text { low } \\
51 \% \text { high }\end{array}$ & $\begin{array}{l}10 \% \text { v. angular } \\
30 \% \text { angular }\end{array}$ & $\begin{array}{l}1.9 \times 10^{-4}\left( \pm 4 \times 10^{-6}\right)^{\mathrm{a}} \\
6.9 \times 10^{-4 \mathrm{~b}}\end{array}$ & $45( \pm 2 \%)$ \\
\hline & $>0.180$ & & $24 \%$ subangular & $1.7 \times 10^{-4 c}$ & \\
\hline & $<0.212$ & & $28 \%$ subrounded & $3.7 \times 10^{-4 \mathrm{~d}}$ & \\
\hline & \#80 & & $\begin{array}{l}7 \% \text { rounded } \\
1 \% \text { well-rounded }\end{array}$ & & \\
\hline $\begin{array}{l}\text { a Measured with falling-head } \\
\text { permeameter }\end{array}$ & Dune sand & $41 \%$ low & $14 \%$ v. angular & $9.6 \times 10^{-5}\left( \pm 2 \times 10^{-6}\right)^{\mathrm{a}}$ & $48( \pm 4 \%)$ \\
\hline${ }^{\mathrm{b}}$ Hazen formula (Vukovic and & $\left(\mathrm{d}_{10}=0.12\right)$ & & $24 \%$ subanoular & $7.1 \times 10^{-5 \mathrm{c}}$ & \\
\hline $\begin{array}{l}\text { Soro 1992) } \\
\text { d Zamarin formula (Vukovic }\end{array}$ & $\left(\mathrm{d}_{60} / \mathrm{d}_{10}=1.6\right)$ & & $\begin{array}{l}27 \% \text { subrounded } \\
15 \% \text { rounded } \\
2 \% \text { well-rounded }\end{array}$ & $1.5 \times 10^{-4 \mathrm{~d}}$ & \\
\hline
\end{tabular}




\section{Procedure}

To conduct an experiment, sands were loaded into the tank, simultaneously with deoxygenated, deionized water, to form saturated columns. Sand poured into the tank from the top settled through a column of water $1-3 \mathrm{~cm}$ thick during the loading procedure, to ensure saturation. The diffuser served as both the air-injection point and the water-entry port. Once loading commenced, no air was allowed to enter the tank through the diffuser until sparging began. These procedures are essentially the same as those reported in Peterson et al. (1999).

\section{Air-flow Indicator}

Air channels and chambers were identified by a colorimetric visualization technique, developed by Peterson et al. (1999), which utilizes the color change of iron filings from black to orangish-brown (oxy-iron hydrate, or "limonite") upon oxidation. Before an experiment, iron filings are in contact with sands and deoxygenated water only. During the experiment, oxygen is provided to the iron filings by the sparge air, but only in the locations where the air pathways are formed in the porous medium, as air migrates from the injection diffuser toward the top of the tank. The orangish-brown color of limonite distinguishes the air-flow locations from the other portions of the sediment column, in which the iron filings remain black. This method required that the sand columns be spiked in an iron:sand volume ratio of 1:10 with ASTM pan \#80 (0.180-0.212 mm) iron filings.

Fig. 3 a Chamber flow in dune-sand experiment after $113 \mathrm{~h}$ of sparging. Schematic inset shows location in tank relative to air-injection point (diffuser). Field of view of photo is $68 \mathrm{~cm}$ across. Metal disks are anti-flexure devices on the tank. b Sketch of region illustrated photographically in a. Air-flow chamber has a significant horizontal component and is distinct from surrounding regions not affected by sparge air

a)

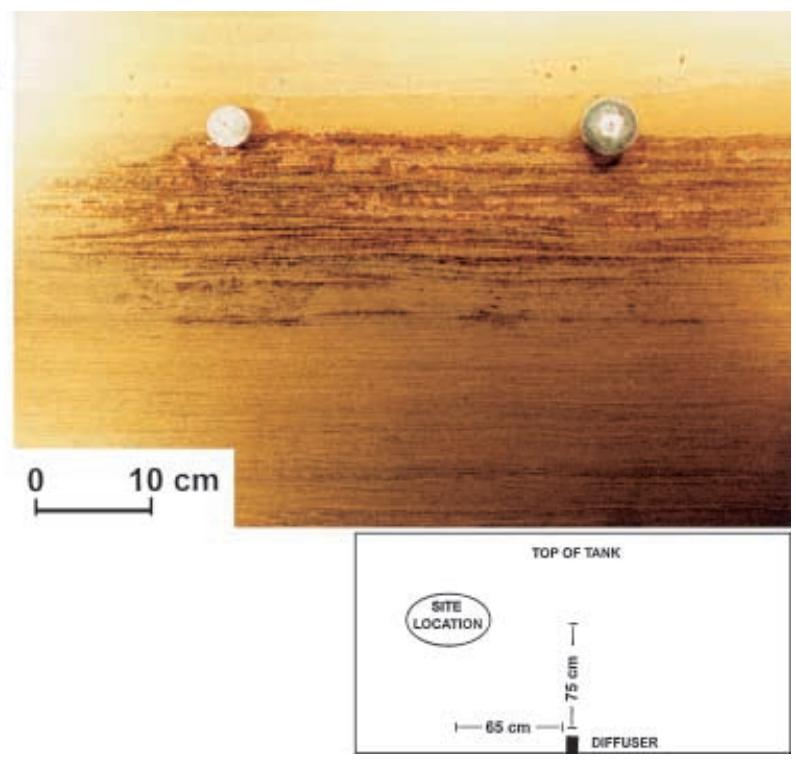

\section{Evaluation}

Air flow was documented at periodic intervals throughout each experiment by photography and by acetate tracings made directly on the tank walls. Tracings of oxidized regions were made on a grid pattern, which allowed a quantitative estimate of the extent of sediment column affected by sparge air. At the end of each experiment, the sparge tank was carefully lowered from the vertical to a horizontal position. A board plug, the same size as the interior dimensions of the tank, was wedged into the tank, on top of the sediment column to prevent slumping of the sand upon rotation. Once horizontal, the upper acrylic wall of the tank was removed to allow systematic excavation of the sediment. Excavation was accomplished by the insertion of numerous, graded ministadia rods in a grid pattern. Sand was removed with thinly bladed spatulas in lifts, or layers, approximately 1-3 cm thick. The stadia rods facilitated a uniform depth of excavation across the tank. After each excavation, oxidized air-flow regions were documented by photography and by tracings on grid acetate. This procedure allowed the spatial documentation of air-flow geometry in the third dimension.

\section{Results}

Figures 3, 4, and 5 are photographs (a) and corresponding sketches (b) of the air-flow regions in sand \#80 and dune sand, as observed by the colorimetric oxidation signal. This flow geometry has not been previously reported in the literature, and the authors propose to call this "chamber flow." Chamber flow is characterized by: (1) a significant horizontal component; (2) pervasive air-flow coverage within a region demarcated by a distinct, irregular boundary; and (3) the presence of predominantly vertical inlet and outlet channels. Figure 3 illustrates the significant horizontal component of chamber flow. The photo was taken of dune sand at the front surface level

b)

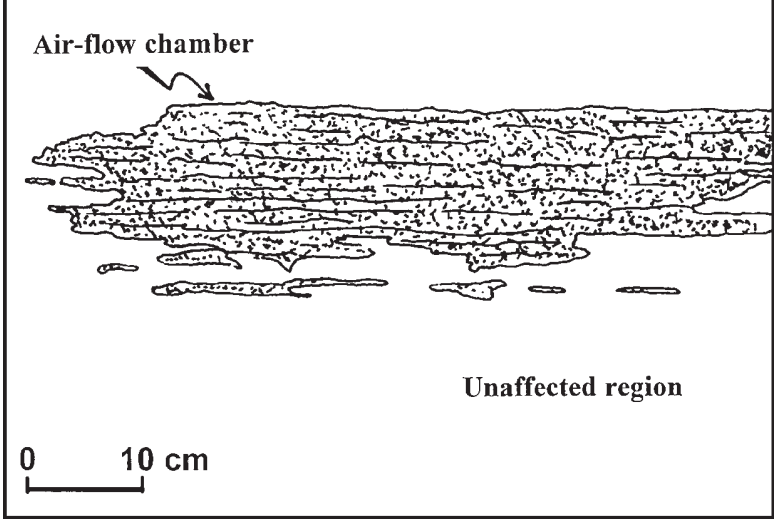


a)

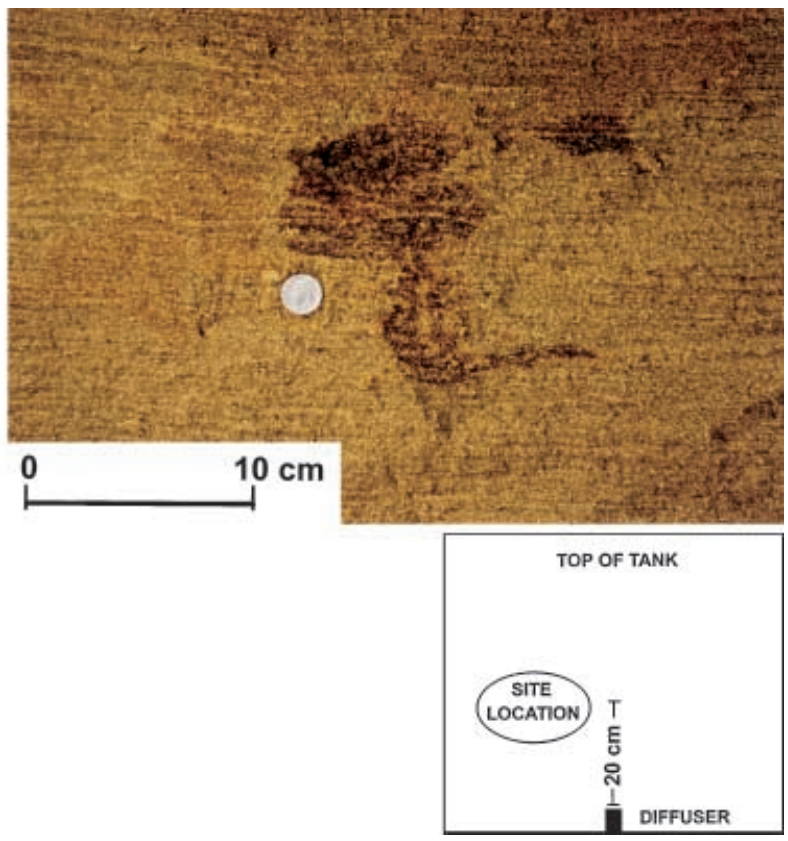

Fig. 4 a Chamber flow in \#80 sand experiment after $144 \mathrm{~h}$ of sparging. Air-flow region is revealed by colorimetric oxidation technique. Schematic inset shows location in tank relative to airinjection point (diffuser). Coin for scale is $1.8 \mathrm{~cm}$ across. b Sketch of region illustrated photographically in a. Chamber shown has a definite, irregular boundary that distinguishes it from surrounding sediment, which is not affected by sparge air

Fig. 5 a Air channel formed in \#80 sand experiment after $144 \mathrm{~h}$ of sparging. This discrete air channel was located at an excavated level of about 2-cm depth, within the sand column. Schematic inset shows location in tank relative to air-injection point (diffuser). Channels like this act as air-flow conduits between chambers illustrated in Figs. 3 and 4. An irregularly shaped chamber occurs at top of air channel. b Sketch of region illustrated photographically in $\mathbf{a}$ b)

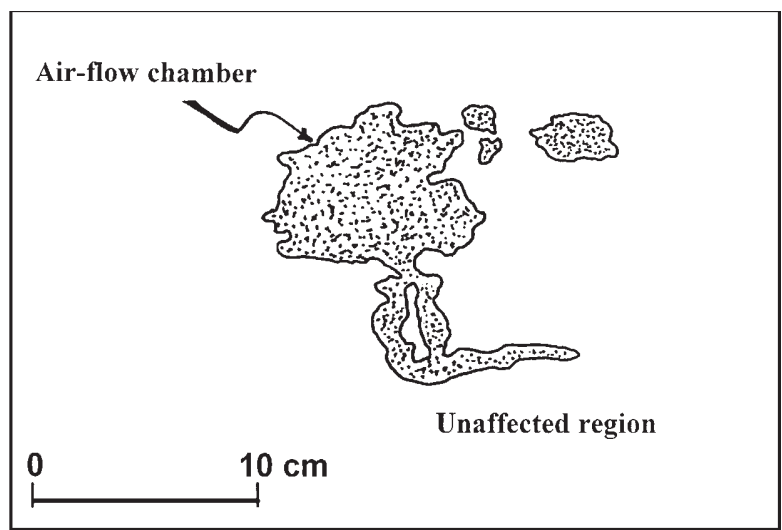

after $113 \mathrm{~h}$ of sparging. Air flow occurred parallel with the stratified horizontal layers of the sediment, but not exclusively. An irregular, predominantly vertical boundary to the air-flow region exists on the left side of the photo. The combination of many horizontal air-flow pathways, with an irregular vertical boundary, forms the overall air chamber, within which pervasive flow occurs. An air-flow chamber is also illustrated in Fig. 4, which is a photo of sand \#80 at the excavated level of approximately $2-\mathrm{cm}$ depth after $144 \mathrm{~h}$ of sparging. Figure 4 also shows that relatively small chambers (4 cm across) can exist in close proximity to larger chambers $(9 \mathrm{~cm}$ across). Figure 5 illustrates one of the air-flow channels that connects the chambers and creates a pathway from the air-injection point to the top of the sediment column. The position of the channel is discordant with respect to the stratified sediment. The air channel shown is from sand \#80 at an excavated level of about 2-cm depth after $144 \mathrm{~h}$ of sparging. Figures 3, 4, and 5 are two-dimensional views of three-dimensional features. The third dimension was verified and tracked by careful excavation of the sediment column. Three-dimensional morphology of air chambers varied from being highly irregular a)

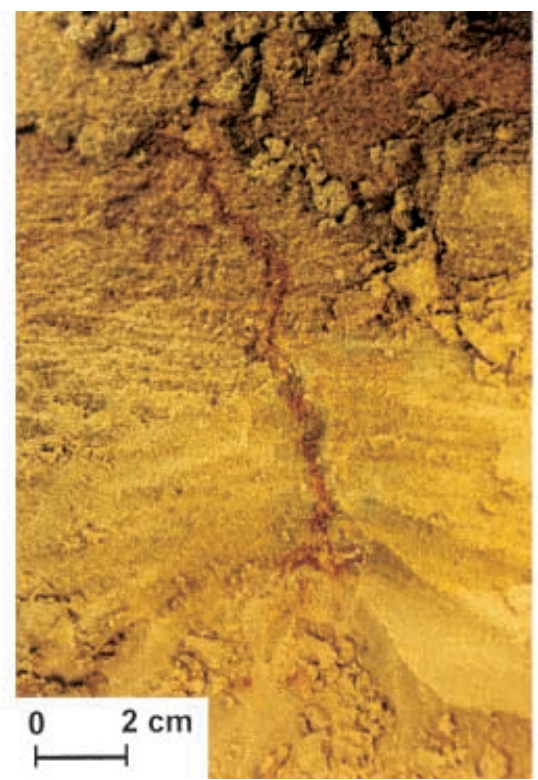

TOP OF TANK

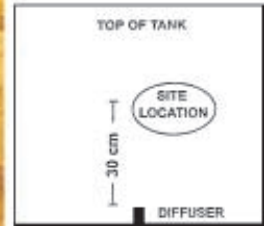

b)

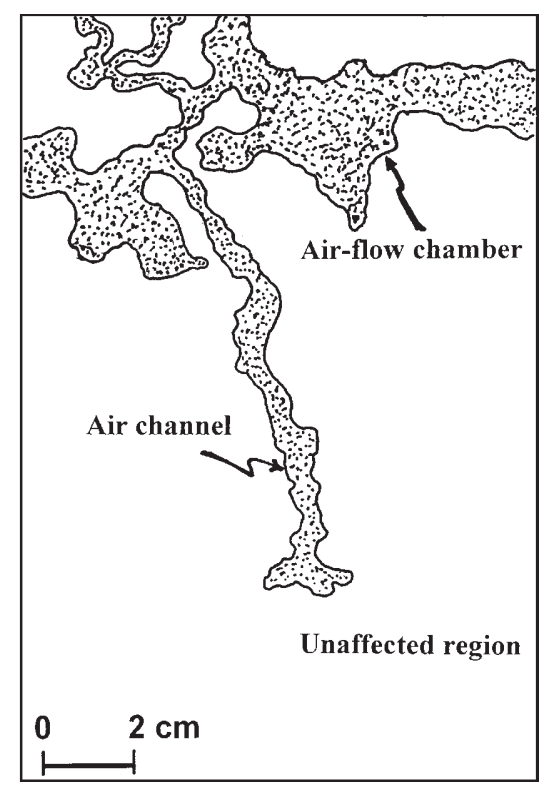


(amoeba-like form; see Figs. $4 \mathrm{~b}$ and $5 \mathrm{~b}$ ), to taking on a tabular form, in which the chamber extends in twodimensions much more than in the third dimension, similar to magmatic sills in igneous rocks.

\section{Discussion}

\section{Comparison with Previous Experiments}

The chamber-flow geometry observed in these experiments is distinctive from channelized flow, which occurs in sediment with grain sizes greater than about $0.18-0.20 \mathrm{~mm}$ in diameter (Table 1). The reason that this flow geometry has not yet been described is probably because virtually all previous visualization experiments in natural sediments were not performed on equivalently small grain sizes. One exception is the $0.08-\mathrm{mm}$ result of Adams and Reddy (1997). Their result is not inconsistent with the observations of the present study, and the differences may be explainable by looking at differences in experimental design. First, the Adams and Reddy (1997) observation of only one or two air channels present in the $0.08-\mathrm{mm}$ sediment is consistent with chamber flow, in which a few air channels act as conduits between air chambers. Second, Adams and Reddy performed experiments in a 9-cm-diameter, 93-cm-high acrylic column. It is quite possible that wall effects in the narrow, tubular apparatus precluded the formation or at least the observation of air-flow chambers. In glass-bead experiments, the widely spaced channels observed by Elder and Benson (1999) in their fine beads $\left(\mathrm{d}_{50} \sim 0.2 \mathrm{~mm}\right)$ suggest the presence of chamber flow.

Results from the study of Adams and Reddy (1997) support the current experimental observations of a significantly different air-flow geometry at grain sizes less than about $0.18-0.20 \mathrm{~mm}$ diameter. The main focus of that study was to investigate the effect of gradation and grain-size distribution on contaminant removal time, and subsequently air-sparging efficiency. Based on experiments, it was determined that a cleanup threshold value exists at an effective grain size $\left(\mathrm{d}_{10}\right)$ of $0.2 \mathrm{~mm}$. At effective grain sizes larger than this value, the cleanup rate, or rate of benzene removal by air sparging, is linearly proportional to the effective grain size. At effective grain sizes less than $0.2 \mathrm{~mm}$, a significant increase (approximately ten times greater; see Fig. 4 of Adams and Reddy 1997) in time is required for benzene removal. This dramatic increase in time required for VOC removal probably corresponds to the transition from channelized air flow to chamber air flow. This is because the rate-limiting step for contaminant removal is the aqueous phase diffusion of VOC to an air pocket. If the locations of air flow are fewer and farther apart, contaminant removal time increases.

\section{Estimates of Affected Area}

Acetate tracings allowed a quantitative estimate to be made of the extent of sediment column affected by the

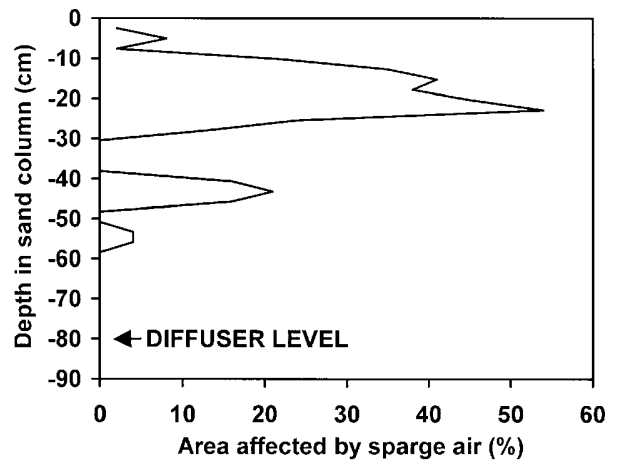

Fig. 6 Relation between area of sand column affected by sparge air and depth. Zero depth is top of dune-sand column spiked with iron and is a few centimeters below water level. See Fig. 1 for reference. Data represent oxidized area on front, vertical face $(x-z$ dimensions) of dune-sand tank experiment after $143 \mathrm{~h}$ of sparging

chamber flow of sparge air. Results are presented in Table 3, along with estimates from previous experiments on larger grain materials, in which channelized and pervasive/bubbly flow occurs. On a two-dimensional basis, calculated by one horizontal dimension $(\mathrm{x})$ and the vertical dimension $(\mathrm{z})$, the area affected by sparging in the dune sand ranges from $4-54 \%$. This large range includes measurements made at each excavated level (y) within the large tank. Figure 6 illustrates the relationship between percent area affected and depth (z) for one horizontal slice (y) within the tank. Four conclusions are made from these data: (1) chamber flow of air in fine- to very fine-grained sands (Wentworth scale) can directly affect an area, ranging from an insignificant percentage of the sediment column (4\%) to a majority of the sediment column (54\%); (2) air-flow chambers are commonly discontinuous, forming distinct boundaries with surrounding sediment over the scale of less than $3 \mathrm{~cm}$; (3) the area affected increases, in a discontinuous manner, with upward vertical distance away from the sparge point; and (4) chamber air flow has the potential to affect a much larger percentage of the sediment column than either channelized or pervasive/bubbly flow. Data collected at individual excavated levels can be combined to yield an estimate of the extent of affected area on a three-dimensional $(x-y-z)$, or volume, basis. As indicated in Table 3, 28\% of the volume of dune sand investigated in the large tank was impacted directly by sparge air.

\section{Applicability of Experiments to the Field}

Some of the observations are due to inevitable layering in the tank. This is particularly true for the significant horizontal component observed in chamber flow. Because non-uniform, heterogeneous, natural sediments are used in experiments, some layering always occurs. This can be understood fundamentally in terms of Stokes' law. Sediments settle through a water column. Any variation in size and density results in some differential settling velocities. This effect tends to be enhanced at smaller effective grain sizes $\left(d_{10}\right)$. Even if the loading 
Table 3 Extent of air impact on sediment column

\begin{tabular}{llc}
\hline $\begin{array}{l}\text { Grain size } \\
(\mathrm{mm})\end{array}$ & $\begin{array}{l}\text { Overall air-flow } \\
\text { geometry }\end{array}$ & $\begin{array}{l}\text { Sediment impacted } \\
(\%)\end{array}$ \\
\hline $\mathrm{d}_{10}=0.12\left(\mathrm{~d}_{60} / \mathrm{d}_{10}=1.6\right)$ & $\begin{array}{l}\text { Chamber } \\
\text { Chamber }\end{array}$ & $\begin{array}{c}28 \text { (volume basis) } \\
4-54(\text { area basis) }\end{array}$ \\
$1.1^{\mathrm{a}}$ & Channelized & 13 (area basis) ${ }^{\mathrm{b}}$ \\
$1.3^{\mathrm{a}}$ & Channelized & $14($ area basis) \\
$1.84^{\mathrm{a}}$ & Pervasive/bubbly & 15 (area basis) $^{\mathrm{b}}$ \\
$2.61^{\mathrm{a}}$ & Pervasive/bubbly & 25 (area basis) $^{\mathrm{b}}$ \\
$4.38^{\mathrm{a}}$ & Pervasive/bubbly & 9 (area basis) $^{\mathrm{b}}$ \\
\hline
\end{tabular}

a Average modal grain diameter (Peterson et al. 1999)

${ }^{b}$ Determined on a $1-\mathrm{m}^{2}$ basis

procedure could involve some kind of media fluidization procedure, turbulent flow tends to sort sediments by size and density (Allen 1977). The only way to avoid layering would be to use uniform-sized glass spheres as a porous medium. An important aspect of the study was to use natural sands, not glass spheres, in an attempt to model natural aquifers. Scaling is the endemic problem in physical laboratory experiments that investigate extensive parameters, as opposed to intensive parameters, such as concentration. Natural sedimentation produces layering. Even aeolian deposits (e.g., sand dunes) have layering according to grain size. The scale of the layering is a function of sedimentation/deposition rate, and of the heterogeneity of the material.

Two other features observed in chamber flow are probably not controlled by horizontal layering: (1) pervasive air-flow coverage within a region demarcated by a distinct, irregular boundary (Fig. 4); and (2) the presence of predominantly vertical inlet and outlet channels (Fig. 5). Because virtually all naturally formed aquifers equivalent in grain size to those examined in this study are layered, and because two out of three geometric features observed in the tanks are probably independent of layering, it is concluded that all the geometric features of chamber flow are applicable to field conditions. The actual dimensions of the amoeba-shaped chambers, the vertical inlet and outlet channels, and the extent of the horizontal flow are functions of sparging operating conditions and field-site stratigraphy.

\section{Implications for Remediation}

Chamber flow of air in fine- to very fine-grained sands has several potential implications for air sparging of VOC-contaminated sites. A positive implication is that a significant percentage of the sediment column can be affected by sparge air, greater than $50 \%$ on an area basis and nearly $30 \%$ on a volume basis. This result indicates that sparging in fine- to very fine-grained sands (i.e., less than $0.25 \mathrm{~mm}$ on the Wentworth scale) could actually have more of an impact on the soil column than previously assumed and determined for channelized flow of air, a conclusion also postulated on theoretical grounds by Clayton (1998). A less comforting implication is that whereas extensive remediation may be possible, minimal spatial impact may also be possible; and in either case, a radius/area of influence would be very difficult to predict. Chamber flow could be a good explanation for variability in remediation performance over relatively short distances at the same site (Bass 1997). One way to maximize the performance of air sparging at a fine-grained site in which chamber flow occurs is to obtain detailed stratigraphic information before system design and installation. A knowledge of the spatial distribution of fine-grained lenses would allow the horizontal aspect of chamber air flow to be utilized as a way to impact large portions of the subsurface with relatively few vertical sparge wells.

\section{Conclusions}

Detailed air-sparging visualization experiments on very fine- to fine-grained sands $\left(\mathrm{d}_{10}=0.12\right.$ and $0.18 \mathrm{~mm}<\mathrm{d}$ $<0.21 \mathrm{~mm}$ ) reveal a third type of air-flow geometry, herein described as "chamber flow." This type of airflow pattern has not been described previously in the literature and is significantly different from either pervasive/bubbly or channelized flow. Chamber flow occurs in grain sizes less than about $0.18-0.20 \mathrm{~mm}$ in diameter and is characterized by: (1) a significant horizontal component; (2) pervasive air-flow coverage within a region demarcated by a distinct, irregular boundary; and (3) the presence of predominantly vertical inlet and outlet channels. The spatial extent to which chamber flow affects the sediment column is highly variable, but its effect may exceed $50 \%$ on an area basis, or nearly $30 \%$ on a volume basis. This study indicates that a detailed knowledge of stratigraphy is important to maximize air-sparging efficiency at sites where chamber flow is likely to occur.

Acknowledgements Research was funded by the National Science Foundation (NSF-EAR-9906721) and a Howard Hughes Medical Institute (HHMI) grant to Hope College.

\section{References}

Adams JA, Reddy KR (1997) The effect of grain size distribution on air sparging efficiency. In: Alleman BC, Leeson A (eds) In situ and on-site bioremediation, vol 1. Battelle Press, Columbus, Ohio, pp 165-172

Allen JRL (1977) Physical processes of sedimentation. Allen and Unwin, London

Bass DH (1997) The effect of grain size distribution on air sparging efficiency. In: Alleman BC, Leeson A (eds) In situ and onsite bioremediation, vol 1. Battelle Press, Columbus, Ohio, pp 117-122

Brooks MC, Wise WR, Annable MD (1999) Fundamental changes in in-situ air sparging flow patterns. Ground Water Monitor Remed 19:105-113

Clayton WS (1998) A field and laboratory investigation of air fingering during sparging. Ground Water Monitor Remed 18: 134-145

Elder CR, Benson CH (1999) Air channel formation, size, spacing, and tortuosity during air sparging. Ground Water Monitor Remed 19:171-181 
Fetter CW (1994) Applied hydrogeology. Prentice Hall, Englewood Cliffs

Freeze RA, Cherry JA (1979) Ground water. Prentice Hall, Englewood Cliffs

Ji W, Dahmani MA, Ahlfeld DP, Lin JD, Hill E (1993) Laboratory study of air sparging: air flow visualization. Ground Water Monitor Remed 13:115-126

Peterson JW, Lepczyk PA, Lake KL (1999) Effect of sediment size on area of influence during groundwater remediation by air sparging: a laboratory approach. Environ Geol 38:1-6

Peterson JW, DeBoer MJ, Lake KL (2000) A laboratory simulation of toluene cleanup by air sparging of water-saturated sands. J Hazardous Mater 72:167-178

Plummer CR, Nelson JD, Zumwalt GS (1997) Horizontal and vertical well comparison for in situ air sparging. Ground Water Monitor Remed 17:91-96
Raymond LA (1995) Petrology: the study of igneous, sedimentary, metamorphic rocks. Wm C Brown, Dubuque

Rutherford KW, Johnson PC (1996) Effects of process control changes on aquifer oxygenation rates during in situ air sparging in homogeneous aquifers. Ground Water Monitor Remed 16:132-141

Vukovic M, Soro A (1992) Determination of hydraulic conductivity of porous media from grain size composition. Water Resources Publications, Littleton, Colorado

Wehrle K (1990) In situ cleaning of CHC contaminated sites: model-scale experiments using air-injection (in-situ stripping) method in granular soils. In: Arendt F, Hinsenveld M, Van Den Brink WJ (eds) Contaminated soils 1990. Kluwer, Dordrecht, pp 1061-1062 